\title{
THE POTENTIAL AND SUPPLY CHAIN OF COCOA IN THE CENTRAL SULAWESI, INDONESIA
}

\author{
Muslimin*, Nersiwad, Tallesang Mukhtar \\ Faculty of Economics, University of Tadulako, Indonesia \\ *E-mail: hasan muslimin@yahoo.co.id
}

\begin{abstract}
Cocoa is a reliance commodity of the plantation that plays a strategic role in national economy, especially as a provider of employment, source of income, and foreign exchange income. This research aims to identify the cocoa potential and the supply chain of cocoa in Central Sulawesi - Indonesia. Type of the research is descriptive research using survey method in the cocoa supply chain in 13 Regencies/Cities in Central Sulawesi. The result of the study shows that: (1) The largest contributor of the cocoa producer in Indonesia is Central Sulawesi with 23.14 percent of national cocoa and 188,600 hectares area. (2) The cocoa supply chain consists of farmers $\rightarrow$ collecting traders $\rightarrow$ wholesalers $\rightarrow$ industry. (3) The risks in the supply chain of cocoa are (1) Price: No access to a certain information about the price of cocoa resulting in the price determined by the trader unilaterally, (2) Pest Risk: cocoa rot disease; Stem cancer, (3) Seasonal Risk: the rainy season can also cause fungal disease in the stems and damage the cocoa fruit, (4) Human Resources Risk: Low awareness of the community on how to maintain cocoa well and how to turn it into the main livelihood.
\end{abstract}

\section{KEY WORDS}

Cocoa, supply chain, risk, Central Sulawesi.

Cocoa is a reliance commodity of the plantation that plays a strategic role in national economy, especially as a provider of employment, source of income, and foreign exchange income. In 2012, cocoa commodity had contributed USD 1,053,446,947 (IDR 1.053 billion) foreign exchange from cocoa beans and processed cocoa products (Ministry of Industry, 2013). However, the national cocoa production is quite concerning because of the declining trend over the past five years. In 2019, the national cocoa production had reached 820.496 tons and it decreased by 5.24 percent to 777.539 tons in 2012 (Directorate General of Plantation, 2014).

Central Sulawesi as one of the largest cocoa producers in Indonesia is now experiencing a downward trend in the number of production from year to year. Cocoa production of Central Sulawesi in 2012 amounted to 117,000 tons or decreased by 30 percent comparing to 2011 production that reached 167,000 tons. The value of cocoa export until September 2013 amounted to USD 29.6 million or decreased by 52.46 percent comparing to the first period of the previous year that reached USD 62.3 million (Head of Representative of Bank Indonesia of Central Sulawesi, 2013).

The decrease in cocoa production is generally caused by the high risk of the cocoa supply chain such as production risk, market risk, and environmental risk. The high risk of the supply chain will give the impact on the household income of the farmers, poverty, economic growth, and fiscal balance (Toure, 2012). Sustainability is a key factor in mitigating the agricultural supply chain risk (Rainforest Alliance, 2012). The continuous cocoa development aims to improve the cocoa productivity by maintaining the environmental sustainability (Directorate General of Plantation, 2013). Therefore, it is necessary to analyze the risk of the cocoa supply chain for continuous cocoa development.

Based on the above background, the problems of this research are as follows:

1. What is the potential and activity of cocoa supply chain in Central Sulawesi?

2. What kinds of risks are considered to be the obstacle in the cocoa supply chain that lowers the cocoa productivity in Central Sulawesi? 


\section{LITERATURE REVIEW}

Supply Chain Management. The main focus of Supply Chain Management (SCM) is to achieve production quality improvement and efficiency through integrated supply chain (SC) (Chin et al, 2006). The effective distribution of management has become an important issue in a business. It is known as supply chain management (SCM), which is a new approach to integrate distribution and production, as one of the most famous management concepts in logistic (Kiefer and Novack, 1999; Ballou, 2007).

SCM is one of the easiest ways to improve the business value by reducing waste through low operational cost (Chase, 1998; Ballou, 2007). Similarly, SCM can also be understood as the philosophy of management (Tan et al., 2002, Chan and Qi, 2003). For example, Lummus and Vokurka (1999, p. 11), reviewed by Ellram and Cooper (1993), who define that "SCM is a philosophy that integrates the management of total expenditure from distribution line and from supplier to the main customers". SCM has been described in many terminologies; supplier integration; partnerships; major supply management, supplier alliance, supply chain balance; (Tan et al., 2002); network lane; supplier pipeline management; supply chain management; and value flow management (Croom at al., 2000; Romano and Vinelli, 2001); and as a demand chain (Kotzab and Otto, 2004 in Vahrenkamp, 1999; Blackwell and Blackwell, 1999).

Supply chain management is an integrated approach philosophy to manage total flow of distribution line from supplier to the main customer (Ellram and Cooper, 1990). This management aims to link both upstream and downstream, inside and outside of their operation with supplier and customer to give value to the main customer with less cost as a whole supply chain (Martin, 1998; Weber, 2002). Effective supply chain strategy is needed to create competitiveness revolving around the accuracy of delivery of competitive quality of goods and services with reasonable cost, including appropriate business partners (Hewitt, 1994; Hobbs et al., 1998; Easton, 2002). Supply chain management is a relatively new concept in the business field. It aims to achieve efficiency on the whole operational function through inventory in uncertain external environment. In several supply chain management literature invoke various disciplines that simplify coordination of material regulation and information as well as suppliers to end users.

The definition of supply chain management is an integration of procurement activity of goods and services, the conversion into semi-finished goods and the final product, and the delivery to the customers Haizer and Render (2010). All of these activities include both purchasing and outsourcing, and other functions that play important role in the relationship between supplier and distributor. On the other hand, Pujawan (2005) states that supply chain management is a network of companies that work together to create and deliver a product to the end users. These companies are usually called suppliers, manufacturers, distributors, stores, or retails and supporting companies such as logistic service company. International logistic management agency defines SCM as a strategic and systematic coordination between companies involved in supplying raw materials, producing goods, and delivering it to the final customers Anatan and Ellitan (2008). Krajewski, et al. (2010) explains that "supply chain management the synchronization of firm's processes with those of its suppliers and customers to match the flow of materials, services, and information with customer demand."

The previous researches conducted by Hammer, 1990; Kurt Salmon Associates Inc., 1993; Anand and Mendelson, 1997; Clark and Hammond, 1997; Lee et al., 1997; Lee and Whang, 2000; Li, 2000; Hult et al., 2004; Kulp et al., 2004; Cai et al., 2006; Shah and Shin, 2007) state that several company's advantages can be improved through a better information relationship between other members of supply chain. The advantages include shorter leadtimes, smaller batch sizes, reduced inventory levels, faster new product design, shorter order fulfillment cycles, better coordination of the supply chain activity and better purchasing, operational, and company's performance.

Supply Chain Risk. According to Deleris and Erhun (2007) operational risk factors include planning errors, lack of raw materials, capacity constraints, quality issue, machine failure or down time, software system failure, imperfect result, efficiency, process changing, 
property losses due to accident/disaster, transportation risks (delay or damage during travel), storehouse risks (imperfect order by the customers, insufficient storage and others), budget expenditure, technological disruptions, terms of agreement (minimum and maximum customer demand) and communication or information system disruptions. Furthermore, the effort to design the model of supply chain risk management cannot be separated from the risks that occur during the flow from the upstream to the downstream.

The challenges of global market and value added of cocoa bring new consequences of increasing competitiveness in the supply chain of cocoa industry. Therefore, it is necessary to identify, asses, and mitigate the risk. Once the priority from chain supply risk is identified, a supply chain management risk in the form of risk management in the supply chain is required (Sijabat, 2012). Risk management is a systematic approach to determine quality management policies, procedures and practices based on risk assessment, risk control, and risk evaluation. Risk management refers to planning, monitoring, and controlling of activity based on information generated by risk analysis activity (The Chartered Quality Institute, 2010).

\section{METHODS OF RESEARCH}

Type of Research. Based on specific objective and research target, the type of this research is defined as descriptive research using survey method. Survey is conducted on cocoa supply chain in Central Sulawesi, Indonesia.

Research Location. The research is located in Central Sulawesi covering 12 Regencies/Cities, namely Palu City, Sigi Regency, Donggala Regency, Parigi Moutong Regency, Poso Regency, Tojo Una-Una Regency, Banggai Regency, Banggai Kepulauan Regency, Banggai Laut Regency, ToliToli Regency, Morowali Regency, North Morowali Regency, and Buol Regency.

Research Design. The research design used to formulate the cocoa supply chain model is started from the analysis of supply chain activity and risk identification of cocoa supply chain.

\section{RESULTS AND DISCUSSION}

Cocoa Potential. Indonesia is one of the largest cocoa producers in the world after Ivory Coast and Ghana. The export destinations of Indonesian cocoa beans are Belgium, Switzerland, China, Germany, Estonia, India, Japan, Malaysia, Netherlands, Singapore, Thailand, East Timor and United States (Directorate General of Plantation, 2015). The largest contribution of cocoa production in Indonesia comes from Central Sulawesi Province. The top five cocoa production areas in Indonesia in 2015 are illustrated in Table 1.

Table 1 - The Top Five Cocoa Production Areas in Indonesia in 2015

\begin{tabular}{|c|l|c|c|c|c|}
\hline \multirow{2}{*}{ No. } & \multicolumn{2}{|c|}{ Province } & \multicolumn{2}{|c|}{ Area } & \multicolumn{2}{c|}{ Production } \\
\cline { 3 - 5 } & & $\begin{array}{c}\text { Surface Area } \\
(000 \mathrm{Ha})\end{array}$ & Contribution & $\begin{array}{c}\text { Production } \\
(000 \text { ton })\end{array}$ & Contribution \\
\hline 1 & Central Sulawesi & 288,6 & $16,74 \%$ & 153,0 & $23,14 \%$ \\
\hline 2 & Southeast Sulawesi & 252,7 & $14,66 \%$ & 105,4 & $15,94 \%$ \\
\hline 3 & South Sulawesi & 247,1 & $14,33 \%$ & 100,8 & $15,25 \%$ \\
\hline 4 & West Sulawesi & 179,5 & $10,41 \%$ & 65,7 & $9,94 \%$ \\
\hline 5 & West Sumatera & 156,0 & $9,05 \%$ & 52,9 & $8,00 \%$ \\
\hline 6 & Indonesia & $1.724,1$ & - & 661,2 & - \\
\hline
\end{tabular}

Source: Statistics Indonesia, 2016.

Cocoa production in Indonesia in 2015 amounted to 661,200 tons with area of $1,724,100 \mathrm{Ha}$. The largest contribution of cocoa producer comes from Central Sulawesi Province with 23.14 percent of national cocoa with area of $188,600 \mathrm{Ha}$. The Southeast Sulawesi contributes $15.94 \%$ with area of 252,700 ha, South Sulawesi $15,25 \%(247,100 \mathrm{ha})$, West Sulawesi 9,94\% (179,500 ha) and West Sumatera with $8 \%(156,000 \mathrm{ha})$. 
Central Sulawesi has a large cocoa plantation potential and it spreads over in 13 regencies/cities. There are four regencies that have contributed to the cocoa production in Central Sulawesi (surface area production), namely Parigi Moutong $(69,318$ ha with 45,500 tons), Sigi (27,680 ha with 23,649 tons), Poso (39,103 ha with 19,149 tons) And Donggala $(30,394$ ha with 19,020 tons). The detail of cocoa producing areas in Central Sulawesi is presented in Table 2.

Table 2 - Cocoa Producer Area in Central Sulawesi of 2015

\begin{tabular}{|c|l|c|c|c|c|}
\hline \multirow{2}{*}{ No. } & \multirow{2}{*}{ Regency/City } & \multicolumn{2}{c|}{ Area } & \multicolumn{2}{c|}{ Production } \\
\cline { 3 - 5 } & Area (ha) & Contribution & Production (ton) & Contribution \\
\hline 1 & Parigi Moutong & 69.318 & $24,02 \%$ & $45.500,00$ & $29,74 \%$ \\
\hline 2 & Sigi & 27.680 & $9,59 \%$ & $23.649,00$ & $15,46 \%$ \\
\hline 3 & Poso & 39.103 & $13,55 \%$ & $19.149,00$ & $12,52 \%$ \\
\hline 4 & Donggala & 30.394 & $10,53 \%$ & $19.020,59$ & $12,43 \%$ \\
\hline 5 & Banggai & 46.467 & $16,10 \%$ & $12.732,00$ & $8,32 \%$ \\
\hline 6 & Tolitoli & 21.154 & $7,33 \%$ & $8.479,95$ & $5,54 \%$ \\
\hline 7 & Morowali Utara & 14.605 & $5,06 \%$ & $6.902,00$ & $4,51 \%$ \\
\hline 8 & Buol & 11.525 & $3,99 \%$ & $5.458,63$ & $3,57 \%$ \\
\hline 9 & Tojo Una-Una & 13.856 & $4,80 \%$ & $4.608,73$ & $3,01 \%$ \\
\hline 10 & Morowali & 6.116 & $2,12 \%$ & $4.608,00$ & $3,01 \%$ \\
\hline 11 & Banggai Kepulauan & 6.907 & $2,39 \%$ & $2.491,29$ & $1,63 \%$ \\
\hline 12 & Banggai Laut & 1.031 & $0,36 \%$ & 274,67 & $0,18 \%$ \\
\hline 13 & Palu & 444 & $0,15 \%$ & 126,20 & $0,08 \%$ \\
\hline & Total & 288.600 & $100,00 \%$ & 153.000 & $100,00 \%$ \\
\hline
\end{tabular}

Source: Central Sulawesi in Numbers, 2016.

All of regencies/cities in Central Sulawesi are cocoa producer. However, there are only five (5) regencies with large potential for cocoa plantation, namely Parigi Moutong, Sigi, Poso, Donggala and Banggai.

According to the Head of Provincial Industry \& Trade Office of Central Sulawesi (2016), the cocoa beans produced by Central Sulawesi's farmers are very suitable for chocolate raw materials because of its good quality and fragrant. These two characteristics attract foreign consumers. However, there is no investor who processes raw material of cocoa to be semifinished or finished products in large scale. Thus, the Central Sulawesi Provincial Government conducts its own processing in smaller scale by establishing "cocoa house".

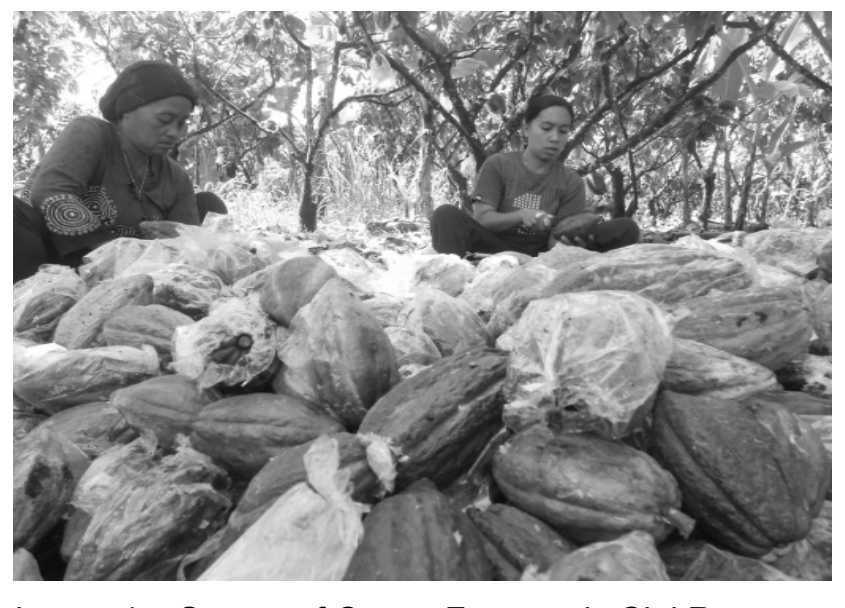

Image 1 - Survey of Cocoa Farmers in Sigi Regency

Cocoa Supply Chain. The cocoa supply chain is a distribution and production line of cocoa starting from upstream to the downstream. Therefore, a close relationship between actors or supply chain agents is needed in order to guarantee the quality and quantity of produced cocoa. The cocoa supply chain in Central Sulawesi consists of three (3) models. 
The first model is a cocoa supply chain model which generally applied in the community of cocoa farmers in Central Sulawesi. This cocoa supply chain model starts from the Farmer community of cocoa - Collecting Trader - Village Traders - Subdistrict Traders District Traders - Province Traders.

Second model of cocoa supply chain is a model starting from Farmers - Collecting trader - Village Traders - Subdistrict Traders - District Traders - Exporting Company. In addition, this line can be started from farmers to the exporting traders through purchasing station.

Third model of cocoa supply chain is a combination model between model 1 and 2 with supply chain agent such as a group of cocoa farmers and farmer cooperative. Thus, it can be directly distributed to the exporting company or manufacturing industry in the region.

Cocoa production starts from the farmers who plant cocoa and produce cocoa beans, this will generate income for farmers. The farmers will sell dried cocoa beans at a price of Rp. 32,000/kg to the collecting trader in rural areas. Then collecting traders hand over the cocoa beans to the wholesalers who come at a certain time or every week or month by offering a price of Rp. 33,000/kg. Wholesalers have two option to sell these cocoa beans, they can sell it to the domestic industry or export it for foreign industry. The sale of cocoa beans in the country by wholesalers is to fulfil the demand of cocoa industry in industrial area of cocoa processing in Makassar. Meanwhile, exporting is intended to fulfil the cocoa processing industry in Malaysia, Singapore, America, Colombia, Brazil and China.

The cocoa supply chain shows that cocoa production is largely depended on the farmers. However, the quality of the cocoa is determined by all supply chain actors because of the intimate relationship among supply chain stakeholders, either farmer, traders or industries. Farmers can sell their cocoa beans at a very high price if they produce highquality of cocoa beans. Traders and industries that are in desperate need of high-quality cocoa beans can produce cocoa products in higher quality and in accordance with the quality standard. Therefore, there must be a close relationship between supply chain actors to develop cocoa in Central Sulawesi.

Cocoa Supply Chain Risk. Based on the result of the survey in the field, there are several risks that obstruct the cocoa supply chain in Central Sulawesi, namely price, pest risk, seasonal risk, human resources risk.

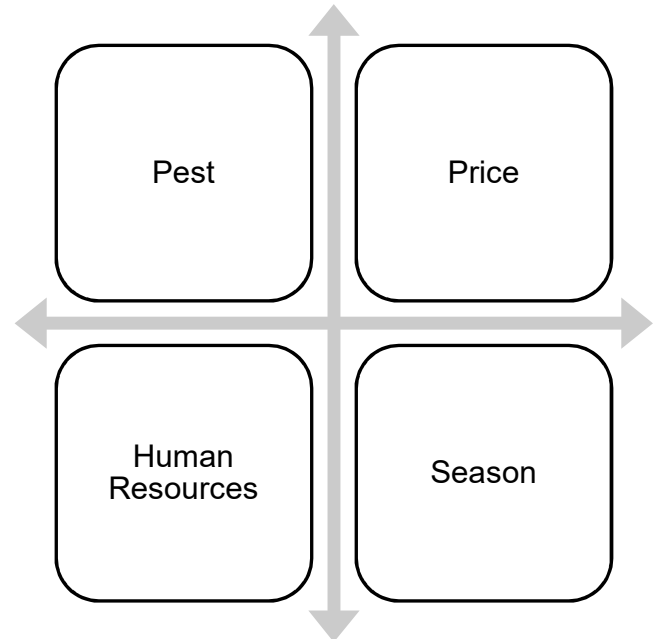

Figure 5 - Cocoa Supply Chain Risk in Central Sulawesi

Price Risk means no access to a certain information about the price of cocoa resulting in the price determined by the trader unilaterally. Pest Risk means cocoa rot disease or Stem cancer. Seasonal Risk means the rainy season can also cause fungal disease in the stems and damaging the cocoa fruit. Finally, Human Resources Risk refers to low awareness of the community on how to maintain cocoa well and how to turn it into the main livelihood. 


\section{CONCLUSION}

Based on the discussion above, it can be concluded that the cocoa supply chain consists of farmers $\rightarrow$ collecting traders $\rightarrow$ wholesalers $\rightarrow$ industry.

The risks in the supply chain of cocoa are (1) Price: No access to a certain information about the price of cocoa resulting in the price determined by the trader unilaterally, (2) Pest Risk: cocoa rot disease; Stem cancer, (3) Seasonal Risk: the rainy season can also cause fungal disease in the stems and damage the cocoa fruit, (4) Human Resources Risk: Low awareness of the community on how to maintain cocoa well and how to turn it into the main livelihood.

\section{REFERENCES}

1. Anand, K.S. and Mendelson, H. 1997. Information And Organization For Horizontal Multimarket Coordination, Management Science, Vol. 43 No. 12, pp. 1609-27.

2. Anatan Lina dan Lena Elitan. 2008. Supply Chain Management Teori dan Aplikasi. Penerbit Alfabeta. Bandung.

3. Badan Pusat Statistik Sulawesi Tengah. 2016. Sulawesi Tengah dalam Angka 2016. Badan Pusat Statistik Sulawesi Tengah, Palu. h. 333-342

4. Badan Pusat Statistik. 2016. Statistik Indonesia 2016. Badan Pusat Statistik, Jakarta. h. 249-270

5. Ballou, R.H. 2007. The Evolution And Future Of Logistics And Supply Chain Management, European Business Review, Vol. 19 No. 4, pp. 342-8.

6. Blackwell, R. and Blackwell, K. 1999. The Century Of The Consumer: Converting Supply Chains Into Demand Chains, Supply Chain Management Review, Fall, pp. 22-3.

7. Cai, S. et al 2006. The Impact Of Interorganizational Internet Communication On Purchasing Performance. Journal of Supply Chain Management, Vol. 42 No.3, pp. 16-29.

8. Chan, F.T.S. and Qi, H. 2003. An Innovative Performance Measurement Method For Supply Chain Management, Supply Chain Management: An International Journal, Vol. 8 No. 3, pp. 209-23.

9. Chase, C.W. Jr. 1998. The Role Of The Demand Planner In Supply Chain Management, Journal of Business Forecasting, Vol. 17 No. 3, pp. 2-24.

10. Chin, K.S., Yeung, I.K. and Pun, K.F. 2006. Development Of An Assessment System For Supplier Quality Managemen, International Journal of Quality \& Reliability Management, Vol. 23 No. 7, pp. 743-65.

11. Clark, T. Dan Hammond, J. 1997. Reengineering Channel Reordering Processes To Improve Total Supply Chain Performance, Production and Operation Management, Vol. 6 No. 3,pp.248-65.

12. Croom, S., Romano, P. and Giannakis, M. 2000. Supply Chain Management: An Analytical Framework For Critical Literature Review, European Journal of Purchasing \& Supply Management, Vol. 2000 No. 6, pp. 67-83.

13. Deleris LA dan Erhun F. 2007. Risk management in a supply network: a case study based on engineering risk analysis concepts, in Handbook of production planning. Kluwer Academic Publishers.

14. Direktorat Jenderal Perkebunan. 2013. Indonesia Menuju Pegembangan Kakao Berkelanjutan.

15. Direktorat Jenderal Perkebunan. 2014. Produksi Kakao Menurut Provinsi di Indonesia Tahun 2009 - 2013, Jakarta.

16. Easton, R. 2002. Seizing The Supply Chain Opportunity In Asia, Ascet, Vol. 4.(The) Economist (1992), April 18, p. 67.

17. Ellram, L.M. et al 1990. Supply Chain Management Partnerships And The Shipper-Third Party Relationship, International Journal of Logistics Management, Vol. 1 No. 2, pp. 1-10.

18. Ellram, L.M. and Cooper, M.C. 1993. The Relationship Between Supply Chain Management And Keiretsu, The International Journal of Logistics Management, Vol. 4 No. 1, pp. 1-12. 
19. Hammer, M. 1990. Reengineering Work:Don"T Automate, Obliterate, Harvard Business Review, Vol. 68 No. 4,pp. 104-13.

20. Heizer. J and Render B. 2010. Operations Management (Manajemen Operasi), Buku 2 Edisi 9 Penerbit Salemba Empat. Jakarta

21. Hewitt, F. 1994. Supply Chain Redesign, The International Journal of Logistics Management, Vol. 5 No. 2, pp. 1-9.

22. Hobbs, J.E., Kerr, W.A. and Klein, K.K. 1998. Creating International Competitiveness Through Supply Chain Management: Danish Pork, Supply Chain Management: An International Journal, Vol. 3 No. 2, pp. 68-78.

23. Hult, G.T.M., Ketchen, D.J. dan Slater, S.F. 2004. Information Processing, Knowledge Development, And Strategic Supply Chain Performance, Academy of Management journal, Vol. 47 No. 2, pp. 241-54.

24. Kementerian Perindustrian. 2013. Industri Kakao Mampu Meningkatkan Devisa Negara.

25. Kepala Perwakilan Bank Indonesia Sulawesi Tengah. 2013. Seminar Nasional Lending Model Pengembangan Kakao Di Sulawesi Tengah, Palu.

26. Kiefer, A.W. and Novack, R.A. 1999. An Empirical Analysis Of Warehouse Measurement Systems In The Context Of Supply Chain Implementation, Transportation Journal, Vol. 38 No. 3, pp. 18-27.

27. Kotzab, H. and Otto, A. 2004. General Process-Oriented Management Principles To Manage Supply Chains: Theoretical Identification

28. Krawjeski, Rizmant dan Malhotra. 2010. Operation Management, Processes and Supply Chains. Ninth Edition, Pearson.

29. Kulp, S.C., Lee, H.L. dan Ofek, E. 2004. Manufacturer Benefit From Information Integration With Retail Customer, Management Science, Vol. 50 No. 4, pp. 431-44.

30. Kurt Salmon Associates Inc. 1993. Efficient Consumer Respon: Enhancing Consumer Value in the Grocery Industry, Food Marketing Institute, Washington, DC.

31. Lee, H.L. and Wang, S. 2000. Information Sharing In Supply Chain, International Journal of Technology Management, Vol. 20 No. 3, pp. 373-87.

32. Lee, H.L., Wang, S. and Padmanabhan, V. 1997. The Bullwhip Effect In Supply Chains, Sloan Management Review, Vol. 38 No. 3, pp. 93-103.

33. Li, L. 2000. Information Sharing In A Supply Chain With Horozontal Competition, Management Science, Vol. 48 No. 9, pp. 1196-212.

34. Lummus, R. and Vokurka, R.J. 1999. Defining Supply Chain Management: A Historical Perspective And Practical Guidelines, Industrial Management \& Data Systems, Vol. 99 No. 1, pp. 11-17.

35. Martin, C. 1998 Logistics and Supply Chain Management: Strategies for Reducing Cost and Improving Service, Pitman Publishing, London.

36. Pujawan, I. N. 2005. Supply chain management. Surabaya: Penerbit Guna Widya.

37. Rainforest Alliance. 2012. Sustainability as a Key Factor for Mitigating Risk in Agricultural Supply Chain Finance, Rainforest Alliance And The Citi Foundation.

38. Romano, P. and Vinelli, A. 2001. Quality Management In A Supply Chain Management Perspective, International Journal of Operations \& Production Management, Vol. 21 No. 4, pp. 446-60.

39. Shah, R. Dan Shin, H. 2007. Relationships Among Information Technology, Inventory, And Profitability: An Investigation Of Level Invariance Using Sector Level Data, Journal of Operation Management, Vol 25 No. 4, pp. 768-84.

40. Tan, K.C., Lyman, S.B. and Wisner, J.D. 2002. Supply Chain Management: A Strategic Perspective, International Journal of Operations \& Production Management, Vol. 22 Nos 5/6, pp. 614-31.

41. Toure, 2012. Ghana Cocoa Supply Chain Risk Assessment. Ghana.

42. Weber, M.M. 2002. Measuring Supply Chain Agility In The Virtual Organisation, International Journal of Physical Distribution \& Logistics Management, Vol. 32 No. 7, pp. 577-90. 